\title{
CONFLICTS IN THE USE OF FOREST LAND IN CANADA
}

\author{
By L. Z. ROUSSEAU ${ }^{1}$
}

If we are to gain some perspective of the problems that we are about to discuss, to wit, "The Conflicts in the Use of Forest Land" throughout Canada, it may be well to consider first, in a general way, why and when such conflicts are most likely to arise.

Essentially, use derives from possession, which is the retention of material things held in property, or of rights peacefully acquired and exercised. It follows from the above definition, that in an organized society, possession is conditioned by the common welfare, and that the exercise of rights carried to its utter limit, abuse, may be questioned whenever it is felt that the public good is endangered.

It is self-evident that the concept of "commonweal" varies according to the degree of technological, scientific, sociological and political development attained by a given group. Science and technology will tend to enlighten the socio-political behavior of this group, to establish, in other terms, the philosophical pattern, the code of ethics by which its members are willing to abide.

But science and technology being in a continuous and constant process of evolution, it can easily be argued that, similarly, patterns of behaviour are also bound to vary. The modifications that they will undergo, though generally slower in rhythm, are due to a quantity of factors, often acting in opposite directions, such as type of tenure, of property, vested interests and privileges, pressure of population, industrial and commercial competition, and communications.

And these are precisely the factors that lead, through their interaction, to those conflicts in use which may eventually-if not inevitably-affect what English jurists call "Estates in land", that is, the combination of land and capital resources regarded by law as land.

In the light of the above definition, land could comprise for instance a complex of agricultural soils, forest stands, hydraulic resources, and mineral deposits, all within the boundaries of a given area, under one ownership. It could thus be conceived as giving rise simultaneously or successively to different types of related or unrelated economic activities according to pressure from external or internal factors, such as an increasing population, a technologically advanced labour force, well developed communications and exceptional outside market demand. In terms of tenure these activities could be conducted either directly by the owner, or, under lease, license of contract, by individuals, co-operatives or corporations.

\footnotetext{
${ }^{1}$ Deputy Minister, Canada Department of Forestry, Ottawa, Ont.
} 
Turning now to conditions of ownership as they prevail in Canada, it is found that as regards forest lands, they occupy some 48 per cent of our total land area, 91 per cent of it being either occupied (21 per cent) or unoccupied (70 per cent) Crown land, while the remainder is privately owned.

In terms of activities conducted on the forested territories, the occupied Crown lands are, with one exception, under renewable lease or temporary permit to forest industrial corporations or companies, while individualsfarmers, or others-and corporations hold in their possession what is known as private forests.

Although it would appear that a large portion of our forested lands is predominantly if not exclusively submitted to the production of lumber, veneer and pulpwood, a closer scrutiny reveals that other industrial and non-industrial agencies enter into play that cut deep inroads into the once undisputed realm of the forester. Among the former, mining and hydroelectric developments are constantly encroaching on the forested lands of British Columbia, Alberta, Manitoba, Ontario, Quebec and the Atlantic Provinces. Thousands of acres of verdant valleys have thus disappeared under the silent accumulation of billions of cubic feet of rising waters, and La Loutre, Mercier, les Passes-Dangereuses, Kitimat and Manicouagan have become symbolic names characterizing one phase of the never-ceasing assault on the Canadian forest.

Stripping of individually less spectacular areas in the quest for the Golden Fleece-or is it iron, copper, nickel or asbestos?-has again laid bare countless acres in each of the aforementioned Provinces, covered with ugly lifeless spoils the flanks of our mountains, and too often reduced to ashes or poisoned with its deadly fumes, square miles over square miles of our forest heritage.

And yet the scourge has brought its own blessings in its wake, contributing to the stature of Canada through the development of our huge mining, metallurgical, and hydro-electric industries.

Other factors and activities should be reviewed that in either direct or indirect fashion affect the use and management of our forest lands. These are: agricultural colonization of forested areas, urbanization and forest recreation in its widest sense, including game and wild life management.

Agriculture, except for the Prairies, has, in the past, developed mainly at the expense of timbered lands. The process of reclaiming arable soil from wooded areas is generally called colonization and it has given birth to a type of humanity, the "settler", the "colon" to which Louis Hemon's "Maria Chapdelaine" has brought literary fame. Notwithstanding our sympathy for this sturdy type of pioneer and for his accomplishments, there remains the brutal fact that most of his energies were too often spent in misdirected efforts to raise agricultural crops where only the patient frugality of trees could be expected to bring appreciable returns.

Over whole townships, Ontario, Quebec and the Atlantic Provinces bear testimony to such futile attempts at agriculture, the most tangible effects of which have been economic stagnation, rural depopulation, tax delinquency 
and presently, the incidence of sizeable problems of reafforestation. A recent survey of submarginal farm lands in Quebec, from Saguenay to the Ontario boundary, on the north shore of the Saint Lawrence, and from the Gaspé Peninsula to the American border and the Saint Lawrence Seaway on the south shore, has shown that some 3,000 square miles of socalled agricultural land should revert to the forest regime: A tall order for any nursery, should a planting program be called for at short notice!

Granting that much of the brunt has been taken out of the urge to open up new territories for agriculture in the East, there are still sporadic manifestations of its vitality in the recent development of so-called "cooperative forest syndicates" whose sole objective is exploitation of the forest without consideration to sustained-yield management. The difficulty here arises from the fact that the idea is taking shape of substantial units of forested land being granted to these syndicates without the financial and technical guarantees which usually accompany the lease of timber limits to bona-fide industrial corporations.

Still another form of conflict originates when farmers are allowed or indirectly solicited to overcut their woodlots through improvident and hastily enacted legislation devised under the pressure of political expediency, and lacking the elementary foundation of a careful assessment of the silvicultural and economic factors that should be considered.

Grazing of wooded lands cannot constitute an important problem in the East, and remains largely confined to the tension zone between the prairie and the open-canopied forest of the foothills of the Rockies. Here again, the decision is whether grazing, afforestation or watershed protection for regulation of streamflow should take precedence and serve the best interests of all concerned. In this connection, I would like to quote a paragraph from an article by the former Chief of the U.S. Forest Service, Richard E. McArdle: "We (foresters) have in the past been concerned mainly with the quality of water, which is a product of watershed protection, and but little with quantity which is the end result of watershed management. We are going to have to think more and more about quantity as well as quality. In many places, water is becoming the chief limiting factor in further urban and industrial expansion. Our cities are reaching out further and further, sometimes for hundreds of miles, to obtain increased supplies of water."

Thus is the problem of urbanization and population growth brought to the fore in its relation to forest lands and forestry practice from an angle often forgotten by Canadian foresters. We have taken for granted our abundant water supply because we have narrowly confined our interest in it by focussing our attention to the immediate problems of the drive, and carefully avoided, as non relevant with our professional duties, consideration of needs, actual or eventual, other than our own. Such needs, however, are also legitimate, and their impact is not restricted to water conservation when we further examine the overall development of population and the phenomena accompanying the growth of our cities in recent years. 
Urbanization is no more to be related to "openfield" regions as the geographers are wont to designate territories long devoted to agricultural pursuits and where cities sprang at commercial cross-roads or favourable portuary locations. They can, almost as if from magic, issue forth from the ground where mineral resources prove important, or industrial or strategic needs dictate. Limited in areal extent though such agglomerations be, they nevertheless suscitate problems in relation to the management of forests and create additional hazards in fire control.

More generally, and coupled with the growth of population in the cities and towns, urbanization has given rise to the ever-increasing pressure resulting from the popularity of forest recreation. Multiplication of accessroads within the forest itself has given a new dimension to vacationing for many who formerly caravaned to the seashore, and provided new fishing and hunting grounds for latent Nimrods and Isack Waltons.

This new invasion of the "sacred woods" of which we have long regarded ourselves as the natural guardians, must be met with intelligence and calls for positive action instead of negative measures and restrictive attitudes on our part. The potential causes of conflict with our traditional concepts of use of our forest lands are thus seen to be economic, social and demographic, to mention but the essential ones.

In consequence of these considerations which apply with varying intensity to the different geographical components of our country, it is imperative that any attempt at solving our problems stem first from a careful study of regional conditions if what the French geographer Jean Gottmann calls "the dynamism of historical change", is to be accelerated, or, at least, preserved. This dynamism is nothing else but the expression of local values peculiar to each region and they more or less constitute symbols around which their population rallies. They cannot be ignored and should be subjected to as intensive a search as the collection and classification of material or physical data. For, if properly evaluated, they counteract the tendency to oversimplify conclusions; and, when conclusions are reached, regarding regions, that should be translated into decisions, they also act as an antidote to overcentralization of authority.

Since regional problems cannot be indifferent to the State and must, in final analysis, be subjected to the formulation of general policy, I appreciate this opportunity afforded to me of restating that our sincerest wish is not only to contribute in their solution to the best of our ability, but with also this aim in view: to harmonize regional views with the best interests of our Country. 